\title{
Candlenut Tree Management on People Forest in Tanah Pinem Subdistrict, Dairi Regency, Indonesia
}

\author{
Tetty Pryska Herawaty Sihombing ${ }^{1 *}$, Hardjanto ${ }^{2}$, Nurheni Wijayanto ${ }^{3}$ \\ ${ }^{1}$ Watershed Management Unit Asahan Barumun, Jalan Viayata Yudha No 108 Pematang Siantar \\ ${ }^{2}$ Department of Forest Management, Bogor Agricultural University, \\ Academic Ring Road, Campus IPB Dramaga, PO Box 168, Bogor 16680, Indonesia \\ ${ }^{3}$ Department of Silviculture, Bogor Agricultural University, \\ Academic Ring Road, Campus IPB Dramaga, PO Box 168, Bogor 16680, Indonesia
}

Received January 10, 2012/Accepted March 13, 2013

\begin{abstract}
Candlenut tree is one of the multipurpose tree species because almost all parts of the plant can be utilized. The candlenut trees grow and are distributed in all provinces of Indonesia. Tanah Pinem in Dairi Regency is one of the candlenut-producer area. The objectives of this study were to learn and describe the management of candlenut tree in Tanah Pinem Subdistrict. The research was conducted with survey method by collecting data in the field. Primary data were obtained through structured interviews, while secondary data were obtained from relevant institutions and previous researches. The data were analyzed and described to learn how the community manage the candlenut tree and the condition at that time. The results showed that the candlenut tree is one of the plants that are beneficial because it can be a source of income for the community and play a role in safeguarding the environmental conditions of Tanah Pinem subdistrict. However, the management of candlenut tree was not intensive. Area size and production of candlenut tree tended to decrease each year. About $90 \%$ of Tanah Pinem subdistrict topography are steep and very steep, and it is necessary to replant the land with trees such as candlenut to protect the land from erosion and landslide hazards.
\end{abstract}

Keywords: candlenut, community, management, production, multi purposes tree species

*Correspondence author, email: tettypryska@yahoo.com, telp.+62-812-6398-636

\section{Introduction}

People forests have developed since long time ago on lands owned by people which are cultivated in self supporting manner. Traditional people forest constitutes the origin of shifting cultivation system which develops into permanent sedentary agriculture. The process of repeated land management by selecting a particular species gradually becomes a form of land management option on the basis of experience and benefit being obtained.

Planting patterns of people forest consist of pure plantation (1 species), mixed species, and agroforestry (Mindawati et al. 2006). Examples of pure plantation people forest are people forest of sengon (Paraserienthes falcataria), teak, and mahogany in Java Island. Mixed people forest comprises combination of several woody species, whereas people forest with agroforestry pattern is combination between forest tree crops and other commodities, such as those of agriculture, plantation, animal husbandry, and fishery.

Development of people forest management by the community is still constrained by many things. Awang et al. (2007) noted that management of people forest is still very simple, namely planting their owned land with woody plants and let the plants grow without intensive management, while Hardjanto (2000) said that people forests which were managed by the community had not exhibited business and sustainability principle, and that the forests had not become the reliable source of income, and the harvesting was still based on the need for cash.

One of the commodities of people forest is candlenut tree species (kemiri). Candlenut has good prospect to be developed in people forest because this species is categorized as multi purposes species, nearly all parts of the candlenut plant could be utilized. The fruit is useful as food seasoning, medicines (laxative, oral ulceration, dysentery, ulcer, hair growth stimulant, skin disorder, shooting pain in the waist), etc, while candlenut oil is used as ingredient for paint, varnish, boat coating, oil lamp, batik industry, and cosmetics (Paimin 1994; Sunanto 1994; Winarbowo \& Manoko 2006), and for protecting wood from termite attack (Nakayama \& Obsbrink 2010). Seed coat (shell) could be utilized as raw materials for burnt mosquito repellent and charcoal (Paimin 1994; Wibowo 2007). Waste residue from oil management could be used as animal feed and as plant fertilizer due to considerably high content of NPK elements, while the candlenut wood could be useful as firewood, matches raw materials, chopsticks, household utensils, packing board, pulp, and veneer/plywood (Paimin 1994; Winarbowo \& Manoko 2006). Candlenut tree could be used as reforestation and afforestation trees due to its rapid 
growth, ease of planting, and simple growth requirements. So they could be used to rehabilitate critical and barren land (Koji 2002; Suhartati 2006; Wibowo 2007).

Development of candlenut plantation management faces problems from time to time in line with the increasing need of human being. Demand is estimated to increase by 10 $20 \%$ year $^{-1}$ (Paimin 1994), while in various places in Indonesia there are changes in plantation area size. Changes in candlenut plantation area size would affect fruit productivity, which will in turn affect the fulfillment of people's need.

One of the centers of candlenut producer is subdistrict of Tanah Pinem, managed by the community in self supporting manner. Area size and production of candlenut plantation in Tanah Pinem Subdistrict tend to decrease. This change is due to various factors, where one of them is change in land use pattern and people's interest in choosing species of plants to be cultivated. Based on these phenomena, this research on candlenut plantation management existing in Tanah Pinem Subdistrict was conducted. The objectives of this research were to learn and describe the management of people's candlenut plantation in Tanah Pinem Subdistrict.

\section{Methods}

The background of this research was the occurrence of change in land uses from candlenut plantation to that of other crops, so that there were changes in candlenut plantation area size for a period of 10 years (Figure 1). On the other hand, land condition in Tanah Pinem Subdistrict is very prone to disaster if there is change in land use pattern because in terms of topography, $90 \%$ of the area is categorized as steep (Table 1). This research tried to study the management of people's candlenut plantation (starting from planting, through production and marketing), the background of land use change from candlenut species to other crop species, and the efforts which are needed to regain the role of candlenut plantation in safeguarding the environment.

The research adopted the survey method (Nazir 2009) due to existence of activities to collect facts and data on existing problems and truth of the prevailing condition.

Research location was determined purposively on the basis of selecting villages which had the largest area of candlenut plantations, namely villages of Pasir Tengah, Pamah, and Kuta Buluh. Research was conducted from March through May 2011. Respondents were farmers who planted candlenut and those who did not plant candlenut. Information on candlenut plantation management and on why the people were still planting candlenut was obtained from people who planted candlenut, whereas from respondents who did not plant candlenut, the obtained information were those on whether they have ever planted candlenut in the past and on why they had shifted from candlenut planting to other species planting, and on other information related with experiences in managing candlenut

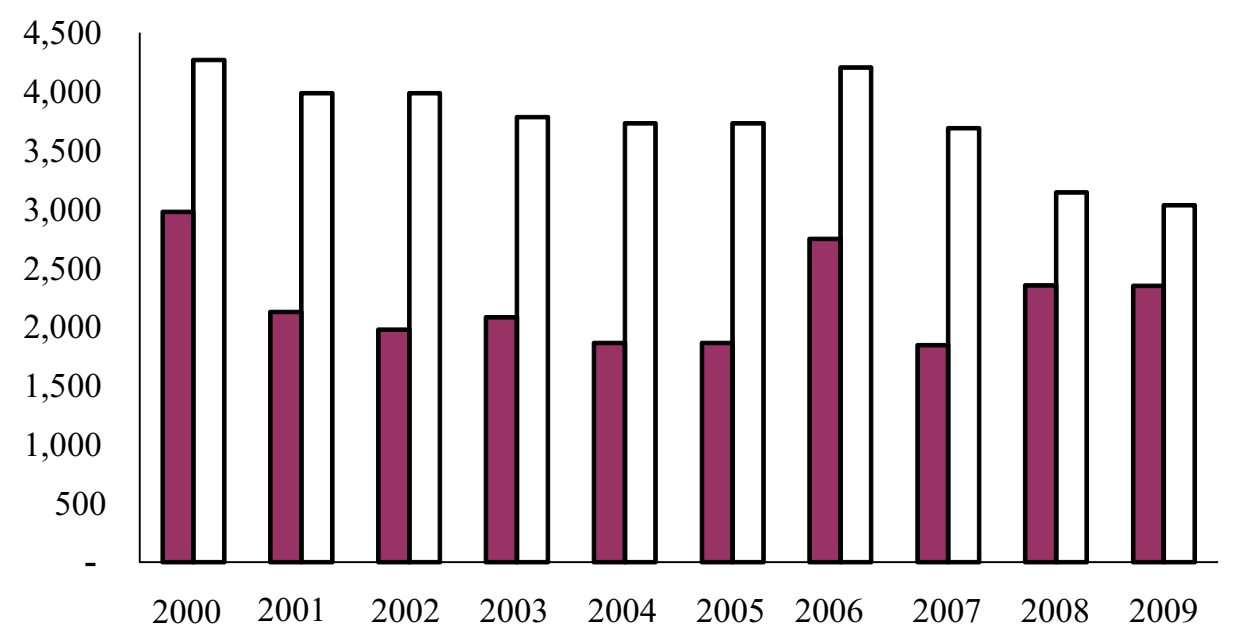

Source: Subdistric Tanah Pinem (2000-2009)

Figure 1 Area size and productivity of candlenut for the past 10 years. Production (ton) ( $\square$ ), area size (ha)( $\square$ ).

Table 1 Topography condition in Tanah Pinem Subdistrict

\begin{tabular}{ccc}
\hline Land condition $\left(^{\circ}\right)$ & Area size $($ ha) & Percentage $(\%)$ \\
\hline Flat $(0-81)$ & 879 & 2 \\
Rolling $(8-15)$ & 1.318 & 3 \\
Undulating $(15-25)$ & 2.197 & 5 \\
Steep $(25-40)$ & 3.955 & 9 \\
Very steep $(>40)$ & 35.591 & 81 \\
\hline Total & 43.940 & 100
\end{tabular}

Source: BPS Dairi District (2009) 
plantation. Determination of respondents was conducted by using Slovin formula (Umar 2000) and sample size was 126 families which were taken proportionally from the 3 villages. In depth interview was conducted to learn things which are related with development of candlenut plantation management which has occurred formerly, up to the time of study. The parties being interviewed were those players of candlenut product marketing (fruit traders, shell/seed coat traders, and wood traders), people who planted candlenut, extension agents, and public figures.

Primary data were obtained from results of structured interview with the predetermined respondents whose topics were farmer's background, pattern of candlenut planting being practiced, management practices being conducted, maintenance efforts, product management, and the marketing. Secondary data were collected from reports from relevant agencies/institutions and existing research results. Data management was conducted with tabulation, followed with quantitative, and qualitative description to explain the candlenut management being conducted by the community in Tanah Pinem Subdistrict.

\section{Results and Discussion}

Planting pattern Candlenut planting pattern was monoculture ( 1 species) as large as $55.56 \%$ and agroforestry (in the form of mixture with other crop species such as betel vine, cacao, coconut, areca nut, durian, clove, etc) as large as $44.44 \%$ (Table 2). The reason for planting candlenut as the sole species was land condition which was situated in steep topography so that it was not suitable to be planted with agricultural crops, and insufficient farm labourers which did not allow diversification of species. Planting of multiple species was conducted due to assurance of additional income.

The average area size of candlenut planting was 2.67 ha. The smallest was 0.45 ha and the largest was 6 ha. The area size of candlenut land owned by the people would affect the number of growing trees and would in turn affect the magnitude of production.

The candlenut plantation owned by the people were originated from inheritance $(47.62 \%)$, had been existing by the time of land purchase $(30 \%)$ and planted by the people themselves $(22 \%)$. Source of planting stocks were from the surrounding areas, privately owned lands, and from forest area (which grew naturally).

The reasons for people to maintain the candlenut plantation was tending operation which was not difficult, no need for fertilizer application, yield and products which could appear everyday, benefit obtained for fulfilling the daily needs, suitability for sloping land, and ability to serve as saving to fulfill the need in the future; and the same reasons for people to manage Talun Garden (Suharjito 2002).

Benefits being obtained from candlenut plantation Benefits which were obtained mostly by the people were fruits, which were obtained in simple manner, without damaging the plants, and environmentally friendly, by collecting fruit which naturally fell under the stand. The utilization of benefit from wood had not been commonly practiced by the people. There were seven respondents $(11.11 \%)$ who have ever sold candlenut timber, whereas the rest had never done it. Not all respondents could sell candlenut timber due to lack of information on the sale of candlenut timber, bad condition of candlenut tree (much branching), very small number of trees with large diameter and round stem, and the effect of distance between location of kemiri plantation site and the road. The farther the distance to the road, the lower would be the price of candlenut timber, and this could reach a very low price, and even no people were willing to buy the timber.

Timber which were in demand for sale were those which were close to the road, having large diameter, and having straight and round stem. Price determination was based on estimation method, and was affected by the number of trees which could be transported in accordance with criteria needed by the buyer, and distance between the timber location and the road, while all logging and transportation cost were shouldered by the buyer, so that the bargaining position of the timber owner was weak (Sumodiningrat 1999; Hardjanto 2000; Awang et al. 2007). In general, the timber owner accepted every price being determined due to reason that it was still better than being unsold.

Plant condition Age limit for candlenut production was 35 years (Paimin 1994; Koji 2002; MoA 2006). Ichwandi (2001) categorized the age class of candlenut plantation into 3 categories, namely young age class $<10$ years, productive (age 11-35 years) and old (>35 years). If candlenut plantation is productive up to the age of 35 years, then those who possessed productive plants were as many as 32 respondents $(50.79 \%)$, while the other 31 respondents (49.21\%) possessed unproductive plants. In Table 3 it could be shown that nearly $50.6 \%$ (84.95 ha) of candlenut plantation had passed the productive age, showing that regeneration process of candlenut plantation was not occuring in sustainable manner (Hasnawir \& Yusran 2000). Candlenut plantation whose age was more than 35 years, remained in production, but their production tended to

Table 2 Pattern of people candlenut plantation

\begin{tabular}{|c|c|c|c|}
\hline Planting pattern & & Number of respondents & Percentage $(\%)$ \\
\hline Candlenut & & 35 & 55.56 \\
\hline Candlenut & + betel vine & 8 & 12.70 \\
\hline Candlenut & + cacao & 4 & 6.35 \\
\hline Candlenut & + cacao + areca nut + betel vine + etc & 16 & 25.40 \\
\hline Total & & 63 & 100.00 \\
\hline
\end{tabular}


Table 3 Production of people candlenut plantation in the year 2010

\begin{tabular}{lccccc}
\hline $\begin{array}{l}\text { Age } \\
(\text { year })\end{array}$ & $\begin{array}{c}\text { Area size } \\
(\mathrm{ha})\end{array}$ & $\begin{array}{c}\text { Production } \\
(\mathrm{kg})\end{array}$ & $\begin{array}{c}\text { Number of trees } \\
(\mathrm{stem})\end{array}$ & $\begin{array}{c}\text { Production per ha } \\
\left(\mathrm{kg} \mathrm{ha}^{-1}\right)\end{array}$ & $\begin{array}{c}\text { Production per tree } \\
\left.\left(\mathrm{kg}^{\text {tree }}\right)^{-1}\right)\end{array}$ \\
\hline $\begin{array}{c}13-35 \\
>35\end{array}$ & 83.00 & 55.686 & 10.209 & 670.92 & 5.45 \\
\hline Total & 84.95 & 42.284 & 9.071 & 497.75 & 4.66 \\
\hline Average & 167.95 & 97.970 & 19.280 & - & 5.08 \\
\hline
\end{tabular}

decrease up to the age of 50 years, because the plants have been more susceptible toward pest and diseases and were easily fell down.

The average age of candlenut plantation was 37.37 years. The youngest plantation was 13 years old, whereas the oldest was 80 years old. Only 5 respondents $(7.94 \%)$ who have ever practiced regeneration with the reason of possession of steeply sloping land and that they still enjoyed considerable amount of income. Regeneration was conducted by planting young plants and or by utilizing natural regeneration.

Productivity of kemiri plants Production of peeled candlenut fruits in the year 2010 is shown in Table 3 . The area size of productive candlenut plantation was 83 ha with average production of $670.92 \mathrm{~kg} \mathrm{ha}^{-1}$, whereas the other 84.95 ha constituted old plantation with average production of $497.75 \mathrm{~kg} \mathrm{ha}^{-1}$. The overall average of fruit production was $583.33 \mathrm{~kg} \mathrm{ha}^{-1}$. Report by extension agent stated that productivity of candlenut plantation in Tanah Pinem Subdistrict in the year 2010 was $520 \mathrm{~kg} \mathrm{ha}^{-1}$, which was less than the average production of Indonesian candlenut in the year 2007, namely $797 \mathrm{~kg} \mathrm{ha}^{-1}$ (MoA 2009). Candlenut production in Tanah Pinem Subdistrict was nearly similar with average production of candlenut in Indonesia which was around 0.5 ton $^{-1} \mathrm{ha}^{-1}$ year ${ }^{-1}$ of peeled seeds (Paimin 1994; Suhartati 2006).

Production of fruit per tree varied, being affected by tree age and health condition of the plant. Candlenut production at productive age (5-35 years old plantation) was $5.45 \mathrm{~kg}$ of peeled seeds tree ${ }^{-1}$, whereas candlenut production for old plantation category ( $>35$ years) decreased to $4.66 \mathrm{~kg}$ peeled seeds per tree. Average candlenut production for the whole sample was $5.08 \mathrm{~kg}$ of peeled seeds per tree. Candlenut production per tree as mentioned above is very small if compared with those of Paimin (1994), MoA (2006), and Suhartati (2006) which mentioned that candlenut trees which grew in fertile area, had their first harvest which could reach $10 \mathrm{~kg}$ of peeled seeds per tree, and at the age of 6 years produced $25 \mathrm{~kg}$ of peeled seeds, at the age of 11-20 years the production would stabilize to around $35-50 \mathrm{~kg}$ tree $^{-1}$ year $^{-1}$, and production of well grown adult candlenut tree could reach $200 \mathrm{~kg}$ of peeled seeds per tree.

Hasnawir and Yusran (2000) mentioned that productivity of people owned candlenut plantation in Maros District was $72.1 \mathrm{~kg} \mathrm{ha}^{-1}$. Darmawan and Kurniadi (2007) mentioned that candlenut productivitiy in Ngada District was in the range of $3.675 \mathrm{~kg}^{-1}$ tree $^{-1}$ year, while those in subdistrict of Soa and Bajawa were on the average $13.02 \mathrm{~kg}^{-1}$ tree $\mathrm{e}^{-1}$ year, those in Ende district were on the average $7.25 \mathrm{~kg}^{-1}$ tree ${ }^{-1}$ year, those in Subdistrict Ende Selatan and Subdistrict of Ndona were on the average $15.09 \mathrm{~kg}^{-1}$ tree ${ }^{-1}$ year. Wibowo (2007) mentioned that production of candlenut in village of Kuala was $62.5 \mathrm{~kg}$ per tree. The varying productivity of candlenut in various places shows that these production were affected by factors of growth site, stand age, plant condition, and environmental factors (seasonal change).

Maintenance/tending of plantation Planting candlenut is not difficult because it involves only planting, clearing of undergrowth vegetation, and waiting for the fruit production. There is no need for fertilizer application, and the field could be left for a long period of time. These phenomena showed that management of candlenut plantation was very simple and not intensive (Koji 2002; Wibowo 2007; Awang et al. 2007). Among all respondents, there were only 3 respondents who routinely conducted maintenance/tending activities, whereas 21 respondents tended the plant only at certain times, 37 respondents conducted plant maintenance during harvest time, and 2 respondents nearly had never conducted maintenance. The maintenance being conducted was clearing of undergrowth vegetation, because this vegetation disturbed the fruit collection activities.

Fruiting season Candlenut trees could bear fruit during the whole time of a year. However, MoA (2006) mentioned that fruit harvest could be conducted between 2-3 times a year. Fruiting season in the research location, if compared with those in the past (in the year 1980s) was far different. In the past, candlenut produced fruit nearly during the whole time of a year, but at present, such fruit production schedule was erratic. This was probably due to the effect of climate change. To stimulate flower formation, there is a need for distinct dry season. If after pollination, there is rainfall, then the flower would fall down and percentage of transformation from flower to fruit would become smaller (MoA 2006). The range of months where there were fruiting season in the research location were from May through July, and from November through January. However, there were also other fruiting months, because not all candlenut trees possesses similar fruiting season. There were some trees which produced fruit outside the usual fruiting season

Fruit harvesting Fruit harvesting was conducted by waiting the fruits to fall down to the ground (Hasnawir \& Yusran 2000). There were no intentional activities of fruit collection because this was related with level of maturity of the fruits which will be obtained. The harvested fruits were collected, peeled from the fruit flesh, and transported home. Transporting candlenut is very difficult due to their heavy weight and the generally long distance from the plantation field to the people' home. Transportation usually was conducted by using motorcycle, and this was referred to as 
"langsir" system.

Marketing of products People sold the peeled candlenut (peeled seeds or kernel) because it was related with higher selling price. There were also some people who sell candlenut without being peeled, with the reason of some pressing needs, such as the need to buy rice. The price of peeled candlenut during the research time ranged Rp22,000.00-Rp25,200.00 per $\mathrm{kg}$, whereas the price of unpeeled candlenut was Rp6.000.00-Rp8,000.00 per tumba (1 tumba $=2$ liters).

For marketing, there were no any difficulties because in nearly all villages, there were local buyers (toke) and middlemen traders which came from outside the villages, so that there were no transportation const during the marketing.

Besides the fruit, the seed coat of candlenut is also in demand for sale since the year 2009 for Rp10,000.00 up to Rp13.000,00 per sack (size of urea fertilizer sack). Since the occurrence of difficulty for obtaining firewood, many industries shifted to use candlenut seed coat, particularly those industries which use dryer.

The channel for marketing candlenut fruit comprises producers, village/subdistrict middlemen trader, big collecting trader (provincial level), inter island traders, and consumers. Up to the year 2005, candlenut from Tanah Pinem Subdistrict were able to enter export market, but after that, there were no export anymore. The existing candlenut production at that time, was for fulfilling the demand from local, regional, and inter island areas.

Creation of employment opportunity Candlenut management created fair amount of employment opportunity for the farmer families and for those outside the farmer families. There were 33 respondents $(52.38 \%)$ who described that candlenut management created employment opportunity for farmers' family, and 30 respondents (47.62\%) who described that besides employment opportunity for farmers' family, there were also employment opportunity for those outside the farmers' family. Wage system was known by the term "sistem dibelahkan" (literally means "system of division") where the workers were paid with half of the candlenuts which they collected.

Income The average income of respondents varied, depending on the type of the main profession, availability of side job, number of working members of the family, and area size of land being managed (Wijayanto 2002). Average amount of income from candlenut plantation was $39.7 \%$ of the total farmer' income, and shows that this could play a role in increasing people' welfare. The greatest income was obtained by large size ( $5 \mathrm{ha}$ ) land owner, namely $66.27 \%$ whereas the smallest was by small size ( $0.45 \mathrm{ha}$ ) land owner, namely only $5.21 \%$.

If income from candlenut farmers was classified on the basis of area size of land ownership, into 3 strata, then the contribution of candlenut plantation to farmer' income were $32.96 \%$ in strata I $(0.45-2 \mathrm{ha}), 24.13 \%$ in strata II ( $>2-4$ ha), and $47.09 \%$ in strata III ( $>4$ ha). Contribution of candlenut toward farmer' income at all strata varied, due to difference in plant productivity, plant ages, health condition of the plants, and level of management intensity.
If income from candlenut is compared with income from people forest with wood as main product, then the income is still greater. Various research results showed that contribution of wood people forest was smaller, namely around 10\% (Hardjanto 2000; Hardjanto 2001; Darusman \& Hardjanto 2006) if compared with gain from non wood people forest, such as damar resin which contributed around $65 \%$ (Wijayanto 2002) and that of kemenyan (benzoin) which contributed more than 50\% (Nurrochmat 2001) up to $60.69 \%$ (Sitompul 2011). This difference was due to phenomenon that income from non wood forest product could be obtained during the whole time of a year, whereas wood product could only be obtained during thinning and final harvest.

The role of candlenut plantation Besides playing role as income source for the people, candlenut plantation also played some role in safeguarding the environmental condition. Under condition of steep topography, high rainfall, and people' profession which are mostly farmers, then all forms of people' activities of land management could have impact on the occurrence of erosion and landslide.

Existence of candlenut plantation on sloping land plays some role in safeguarding the soil from erosion and landslide because soil surface layer under candlenut stand is covered with undergrowth vegetation. Dense crown of candlenut trees and the undergrowth could protect the soil from rainfall impact, so that erosion could be minimized.

Interest of the people to plant candlenut When candlenut was not yet in demand for sale in the market, the fruits were utilized to fulfill the daily needs, such as for spices, stomach ache remedy, ulcer remedy, and fuel for illumination lamp. Candlenut started to be traded around 1955. Production of peeled candlenut in 1980s could reach 100 ton each week. Livelihood of the residents at that time was as candlenut farmers. Condition started to change since the occurrence of pest and disease attack such as in the form of leaf eating caterpillar, stem borer, and falling fruits around 1987 up to 1990s. Change from rainy to dry season affect the flowering season and fruiting season. Production of candlenut fruits started to decrease and the cheap price started to cause people to shift to plant agricultural crops. Around the year 1997, up to the early 2010, price of peeled candlenut ranged $\mathrm{Rp2,450.00-Rp9,000.00} \mathrm{per} \mathrm{kg}$, while the selling price of agricultural crop was higher.

Change in people's interest was shown by several respondents who did not plant candlenut anymore. There were $66.67 \%$ (42 respondents) who have ever planted candlenut, but at the present time shifted to plant other crops. The reason for respondents to cut their candlenut trees were because the trees have been old (11 respondents), they shifted to other crops (19 respondents), and the candlenut have not produced fruit anymore (1 respondent), while the rest of them did not have any reason. The reasons for respondents to not plant candlenut anymore were because they were not interested anymore (33 respondents), cheap selling price (4 respondents), and decreasing harvest yield ( 2 respondents), while the rest of them explained reasons of pest and disease problem for the plants.

When the research was conducted, selling price for 
peeled candlenut was considerably high, ranging between Rp20,000.00 to Rp25,200.00 per kg, so that many people maintained their candlenut plantation, conducted more intensive maintenance, and conducted regeneration. This condition created impact in the form reduction of cutting of candlenut trees in sloping land.

Consideration of replanting efforts Topography condition of Tanah Pinem Subdistrict showed that $90 \%$ of the area was categorized as steep with slope $>25 \%$. For preventing erosion and landslide, there were efforts to plant trees. In this case, multi purpose tree species constitute the alternative to be developed to become sustainable income source for the people.

As anticipation to prevent erosion and landslide and for increasing again the role of candlenut tree in the aspect of economy and ecology, there is a need for replanting efforts with the following consideration:

1 Topography condition

The area size of Tanah Pinem Subdistrict which was categorized as steep was 39,546 ha or nearly $90 \%$ of the total area of the land. Plant species which are suitable to be developed are those species which possess strong rooting system, perennial plant species, and locally endemic species. Agricultural crops, such as corn is not so suitable to be planted in sloping land because land management with system of land clearing could cause erosion which reduce soil fertility. Candlenut constitutes a suitable plant species to be developed in sloping land because of its fast growing character and is useful in terms of economic and ecologic aspect.

2 Critical land

Area size of critical land in Tanah Pinem subdistrict, according to Watershed Management Unit (WMU) Wampu Sei Ular in 2010 was 30,718.44 ha or around 70\% of the total land area. This phenomenon showed that there is a need for forest and land rehabilitation efforts to increase the role of land as production media and water regulating media. Activities which could be conducted are reforestation in forest territory and afforestation outside the forest territory.

3 Regeneration of plants

People owned candlenut plantations have not shown sustainable regeneration in producing fruits. For recovering the function of candlenut plantation as a product of people forest, there is a need to conduct plant regeneration to gain income for the people. The regeneration method could be adopted to approach the criteria of sustainability in plantation forest.

4 Rehabilitation with conservation technique

For lands which have not been productive anymore and are situated in steep topography, there could be rehabilitation efforts through planting and soil conservation. Techniques of soil and water conservation could be practiced mechanically by among others soil tillage along contour lines, construction of bund, terrace, and other structures (Suripin 2004). Planting of candlenut in sloping land should be conducted along contour lines (across the slope) with terrace system, with the objectives that plant roots would retard the flow of surface runoff, and there would be water absorption and prevention of loss of soil humus due to erosion.

5 Adopting effective planting pattern

In order to make the land function effectively as tree growing medium and to increase land productivity, the planting pattern which will be used is better to be triangular pattern, because the number of plants being planted will be higher than square pattern. If planting distance is $8 \times 8 \mathrm{~m}$, then the number of trees being planted is 156 trees ha ${ }^{-1}$ (following square pattern), whereas if triangular pattern is used, the number of trees being planted is 175 trees $^{-1}{ }^{-1}$ (Paimin 1994). This planting pattern is also suitable for land with steep topography.

6 Field extension program of forestry

Existence of farmer group indicated that access of extension program for the people was available and could play some role for increasing people welfare through introduction of agricultural facilities and infrastructure. Empowerment of farmer group could be extended to the field of forestry with the objectives of recovering the role of land as production media and water regulator. Extension agents have roles to train people to cultivate candlenut and other forestry plants.

7 Market and its relation with development

Marketing of candlenut is not difficult because demand tended to increase every year in line with increasing human population (Paimin 1994). From 1975 through 1995, Indonesia constitutes one of the countries which exported candlenut. In 1996-2003 there were no exports, while in the year 2004-2005 there were export again (MoA 2009). However, in 2004 Indonesia conducted candlenut import as large as 13 tons $(62,000$ US\$) and that in 2005 as large as 15 tons $(27,000$ US\$). Since the year 2005, Indonesia did not export candlenut anymore. There had been no serious attention to develop candlenut for fulfilling domestic needs. If candlenut management is conducted by the government through pattern of people forest development, the role of candlenut as foreign exchange source, local income source, people' income source, and as plants with environmental benefits, could be significantly felt. For this purpose, the government need to implement special program to empower people in the form of development of people forest, community based forest and people plantation forest (inside forest territory) and industrial plantation forest for supporting the supply of plywood raw materials.

\section{Conclusion}

Management of people candlenut plantation could provide economic benefit as income source for the people, and ecological benefit for the environment (as protection from erosion hazard and landslide). Change in land use pattern from candlenut plantation to agricultural crop caused decrease in candlenut plantation area size. Reasons for the cutting down of candlenut plantation were unproductive plantation which was related with plant ages, problem of pest and diseases, low selling price, and decrease of people' interest. With steep and very steep topography condition, the plant species being planted are those species which are able to provide income for the people in sustainable manner, but 
are still able to function in safeguarding the environment. Candlenut plant is multipurpose tree species because of its ability to produce fruits which could be harvested every year, and its ability to protect soil and water and to provide employment opportunity for the people. This showed that candlenut plantation possessed multiplier effect.

\section{Recommendation}

Demand for candlenut fruit which increased every year to fulfill the need of people and industry showed that candlenut plant has prospect to be developed. Research on social and cultural role of the people in developing candlenut plantation need to be conducted to learn the supporting factors and the non supporting factors, so that the development opportunity in the future could be identified. There is also the need for research on model of people forest which is suitable with steep and very steep topographic condition, so that the developed model of people forest could provide economic benefit for the people and the local government, and have beneficial effects toward environment.

\section{References}

Awang SA, Wiyono EB, Sadiyo S. 2007. Unit Manajemen Hutan Rakyat: Proses Konstruksi Pengetahuan Lokal. Cetakan Pertama. Yogyakarta: Banyumili Art Network.

[BPS] Badan Pusat Statistik Kabupaten Dairi. 2009. Kabupaten Dairi Dalam Angka 2009. Sidikalang: Badan Pusat Statistik Kabupaten Dairi.

Darmawan S, Kurniadi R. 2007. Studi pengusahaan kemiri di Flores, NTT dan Lombok, NTB. Info Sosial Ekonomi $7(2): 117-129$.

Darusman D, Hardjanto. 2006. Tinjauan ekonomi hutan rakyat. In: Kontribusi Hutan Rakyat Dalam Kesinambungan Industri Kehutanan. Proceeding Seminar Hasil Litbang Hasil Hutan 2006; Bogor, 21 September 2006. Bogor: Pusat Penelitian dan Pengembangan Hasil Hutan.

Hardjanto. 2000. Beberapa ciri pengusahaan hutan rakyat di Jawa. In: Didik S, editor. Hutan Rakyat di Jawa. Peranannya dalam Perekonomian Desa. Bogor: Program Penelitian dan Pengembangan Kehutanan Masyarakat Fakultas Kehutanan IPB.

Hardjanto. 2001. Kontribusi hutan rakyat terhadap pendapatan rumah tangga di Sub DAS Cimanuk Hulu. Jurnal Manajemen Hutan Tropika 7(2):47-61.

Hasnawir, Yusran. 2000. Analysis of management of private candlenut forest Aleurites mollucana Wild in district Maros South Sulawesi. Buletin Penelitian Kehutanan 6(1): 85-98.

Ichwandi I. 2001. Dampak krisis ekonomi terhadap usaha kehutanan masyarakat: studi kasus di Kabupaten Maros, Sulawesi Selatan. In: Dudung D, editor. Resiliensi Kehutanan Masyarakat di Indonesia. Bogor: Debut
Press.

Koji T. 2002. Kemiri (Aleurites moluccana) and forest resource management in Eastern Indonesia: an ecohistorical perspective. Asian and African Area Studies 2: $5-2$.

Mindawati N, Wididarti A, Rustaman B. 2006. Hasil-hasil litbang yang mendukung hutan rakyat. In: Nugroho SP, editor. Review Hasil Penelitian Hutan Rakyat. Prosiding diterbitkan oleh: Pusat Penelitian dan Pengembangan Hutan Tanaman. Bogor: Badan Penelitian dan Pengembangan Kehutanan.

[MoA] Ministry of Agriculture. 2006. Pedoman Budidaya Kemiri (Aleurites moluccana Willd). Jakarta: Direktorat Jenderal Perkebunan.

[MoA] Ministry of Agriculture. 2009. Kemiri (Candlenut). Statistik Perkebunan Indonesia (The Crops Estate Statistic of Indonesia) 2007-2009. Jakarta: Direktorat Jenderal Perkebunan.

Nakayama FS, Osbrink WL. 2010. Evaluation of Kukui oli (Aleurites moluccana) for controlling termites. Industrial Crops and Products 31:312-315. http://dx.doi.org/10.1016/j.indcrop.2009.11.009.

Nazir M. 2009. Metode Penelitian. $7^{\text {th }}$ edition. Bogor: Ghalia Indonesia.

Nurrochmat DR. 2001. Dampak krisis ekonomi dan moneter terhadap usaha kehutanan masyarakat: Kemenyan di Tapanuli Utara. In: Dudung D, editor. Resiliensi Kehutanan Masyarakat di Indonesia. Bogor: Debut Press.

Paimin FR. 1994. Kemiri, Budidaya dan Prospek Bisnis. Jakarta: Penerbit Swadaya.

Sitompul M. 2011. Kajian pengelolaan hutan kemenyan (Styrax sp.) di Kabupaten Humbang Hasundutan, Propinsi Sumatera Utara [thesis]. Bogor: Graduate School, Bogor Agricultural University.

Suharjito D. 2002. Choices of forest-garden crops: a study of peasant's decision making. Jurnal Manajemen Hutan Tropika 8(2):47-56.

Suhartati. 2006. Management of candelnut farm forest in Sulawesi. Info Hutan Tanaman 1(2):77-85.

Sumodiningrat G. 1999. Pemberdayaan Masyarakat dan Jaringan Pengaman Sosial. Jakarta: Gramedia Pustaka Utama.

Sunanto H. 1994. Budidaya Kemiri Komoditas Ekspor. Cetakan pertama. Yogyakarta: Kanisius.

Suripin. 2004. Pelestarian Sumberdaya Tanah dan Air. Yogyakarta: Andi. 
Umar H. 2000. Riset Pemasaran dan Perilaku Konsumen. Jakarta: Gramedia Pustaka Utama.

Watershed Management Unit Wampu Sei Ular. 2010. Up Dating/Riview Lahan Kritis di SWP DAS Wampu Sei Ular. Buku: Laporan Akhir. Medan: BPDAS WSU.

Wibowo S. 2007. Pengusahaan kemiri (Aleurites mollucana) di Desa Kuala, Tiga Binanga, Tanah Karo. Info Sosial
Ekonomi 7(2):71-77.

Wijayanto N. 2002. Contribution of repong damar to regional economic and income distribution. Jurnal Manajemen Hutan Tropika 8(2):1-9.

Winarbowo S, Manoko IP. 2006. Kemiri (Aleurites moluccana L. Willd) tanaman industri potensial. Warta Penelitian dan Pengembangan Tanaman Industri 12(2):13-15. 